\title{
Analisis Faktor Perlindungan Konsumen Dalam Urgensi Pembentukan Undang-Undang Pinjaman Online (Peer To Peer Lending)
}

\author{
Helena Toshely Sasmita, Suci Kamilah, Rina Irsni Wardodo, \\ Thody Daniel Satya Wira Wicaksana \\ sckamilah@gmail.com \\ Universitas Airlangga
}

\begin{abstract}
Keywords: $\quad$ Abstract
Consumer Financial Technology (Fintech) is currently developing in Indonesia. This is due to the Protection; development of increasingly advanced and sophisticated technology and the presence Constitution; of fintech types of peer-to-peer lending that offer loans easily and quickly. The purpose Financial of this study is to examine and analyze consumer protection factors in the urgency of Technology. establishing an online lending law (peer-to-peer lending). This type of research uses normative legal research methods, with a statutory approach and a conceptual approach. Various problems in the use of online loan services (fintech), including in terms of interest rate transparency, misuse of consumer personal data by lending companies, and collection methods that are not following legal rules, while in Indonesia the legal basis for online loan services is only accommodated by POJK No. 77/POJK.01/2016 which has not been able to fully accommodate all aspects of consumer protection such as the mechanism for monitoring online loan services, guarantees for consumer protection for the use of online loan services, and regulations regarding operating permits for fintech peer to peer lending. With the establishment of the online loan law, it is hoped that it will provide legal certainty for consumers in using online loan services today.
\end{abstract}

Kata Kunci:
Perlindungan
Konsumen;
Undang-Undang;
Fintech.

\begin{abstract}
Abstrak
Financial Technology (Fintech) saat ini sedang berkembang di indonesia. Hal ini dikarenakan perkembangan teknologi yang semakin maju dan canggih serta kehadiran fintech jenis peer to peer lendingyang menawarkan pinjaman dengan mudah dan cepat. Tujuan penelitian ini adalah untuk mengkaji dan menganalisis faktor-faktor perlindungan konsumen dalam urgensi pembentukan undangundang pinjaman online (peer to peer lending). Jenis Penelitian ini menggunakan metode penelitian hukum normatif, dengan pendekatan peraturan perundangundangan (statute approach) dan pendekatan konseptual (conseptual approach). Berbagai permasalahan dalam penggunaan layanan pinjaman online (fintech) diantaranya adalah dari segi transparasi suku bunga, penyalahgunaan data pribadi konsumen oleh perusahaan pemberi pinjaman serta cara penagihan yang tidak sesuai dengan aturan hukum, sedangkan di Indonesia dasar hukum layanan pinjaman online hanya diakomodasi oleh POJK No. 77/POJK.01/2016 yang belum dapat sepenuhnya mengakomodasi seluruh sisi perlindungan konsumen seperti mekanisme pengawasan layanan pinjaman online, jaminan perlindungan konsumen atas penggunaan layanan pinjaman online dan aturan mengenai izin operasi fintech peer to peer lending. Dengan dibentuknya Undang - Undang pinjaman online diharapkan dapat memberikan kepastian hukum bagi konsumen dalam penggunaan layanan pinjaman online saat ini.

Copyright () 2022 Helena Toshely S., Suci Kamilah, Rina Irsni W., Thody Daniel Satya W.W. (c) (i) Published in Media Iuris. Published by Universitas Airlangga, Magister Ilmu Hukum.
\end{abstract}




\section{Pendahuluan}

Pembahasan mengenai hukum dan ekonomi menjadi sebuah kajian yang sangat kompleks dan komprehensif apabila dikaitkan dengan arah pembangunan hukum yang semakin berfokus pada paradigm ekonomi. Antara hukum dan ekonomi masing-masing merupakan suatu aspek yang saling berkaitan dan saling membutuhkan satu sama lain. Korelasinya dapat dipahami dengan aktivitas ekonomi yang selalu mengejar keuntungan yang sebesa- besarnya perlu dibatasi dengan aturan hukum agar tidak terjadi kegiatan ekonomi yang illegal yang mana dapat memberikan kekacauan dan kerugian di antara Stakeholder perekonomian. ${ }^{1}$ Maka dari itu dalam perkembangan teknologi yang berjalan saat ini berbagai macam bentuk baru kegiatan dalam perekonomian haruslah dapat selalu terakomodasi dalam sistem pengaturan hukum di suatu negara. Salah satu perkembangan kegiatan dalam bidang ekonomi yang memanfaatkan perkembangan teknologi adalah terkait kegiatan pinjaman online atau dikenal dengan fintech peer to peer lending.

Pinjaman online atau fintech peer to peer lending saat ini sedang banyak diminati dan berkembang di Indonesia. Hal ini disebabkan karena, layanan pinjaman online dinilai lebih memudahkan masyarakat. ${ }^{2}$ Fintech atau Financial Technology merupakan suatu bentuk baru yang memadukan perkembangan teknologi dengan fitur jasa keuangan. Fintech merupakan suatu evolusi lembaga keuangan konvensional yang tidak memerlukan gedung sebagai tempat fisiknya. ${ }^{3}$ Dengan ciri khas tersebut akhirnya perkembangan perusahaan terdaftar yang berbasis Financial Technology di Indonesia pada tahun 2016 meningkat hingga 165 perusahaan terdaftar. ${ }^{4}$

\footnotetext{
${ }^{1}$ Suyikno, Hukum Ekonomi (UIN Sunan Ampel bekerjasama dengan Government of Indonesia (GoI) dan Islamic Development Bank (IDB) 2015).[35]

${ }^{2}$ Istiqamah , 'Analisis Pinjaman Online Oleh Fintech Dalam Kajian Hukum Perdata' (2019) 6 Jurispridentie : Jurusan Ilmu Hukum Fakultas Syariah dan Hukum.[100].

${ }^{3}$ Posma Sariguna Johnson Kennedy, 'Literature Review: Tantangan Terhadap Ancaman Distruptif dari Financial Technology dan Peran Pemerintah Dalam Menyikapinya' (2017) 6 Prosiding Forum Keuangan dan Bisnis Indonesia (FKBI).[172-173].

${ }^{4}$ Aam Slamet Rusydiana, 'Bagaimana Mengembangkan Industri Fintech Syariah di Indonesia? Pendekatan Interprettive Structural Model (ISM)’ (2018) 6 Jurnal Al-Muzara'ah.[118].
} 
Fintech saat ini menjadisalahsatu pionir penerapan teknologi informasi dibidang keuangan. Pada dasarnya Fintech adalah bagian dari dunia start-up yang memiliki fokus untuk memaksimalkan penggunaan teknologi guna mengubah, mempercepat, atau mempertajam berbagai aspek dari layanan keuangan yang tersedia pada saat ini. ${ }^{5}$ Fintech juga merupakan lini bisnis yang berjalan berdasarkan penggunaan perangkat lunak untuk menyediakan layanan keuangan secara online. Sehingga Fintech memberikan kemudahan akses kepada masyarakat mengenai metode pembayaran, transfer dana, pinjaman, pengumpulan dana, hingga pengelolaan aset. ${ }^{6}$

Menurut jenis layananya, Fintech sendiri dibagi menjadi crowdfunding, microfinancing dan yang penggunaannya menjadi polemik dimasyarakat saat ini adalah peer to peer landing. Bidang yang paling sering digunakan adalah dibidang Payment, Crowfunding dan peer to peer landing. ${ }^{7}$ Fintech dengan jenis peer to peer landing merupakan bentuk peminjaman uang kepada masyarakat melalui pemanfaatan teknologi informasi dengan syarat yang relatif mudah dan cepat sehingga memberikan dampak besar terhadap daya finansial masyarakat. ${ }^{8}$ Hal ini terbukti melalui meningkatnya penawaran produk barang dan/jasa yang dijual melalui e-commerce akibat berkembangnya Fintech. Peningkatan yang terjadi terjadi secara signifikan sebagaimana tercantum dalam Survei Perilaku Konsumen e-Commerce Indonesia Juni 2021 yang mencatat nilai transaksi e-commerce pada tahun 2019 adalah sebesar 205,5 triliun dan pada tahun 2020 kemudian naik menjadi 266,3 triliun atau naik sebesar 29,6\%, kenaikan yang sangat signifikan tersebut salah satunya dilatar belakangi oleh keyakinan masyarakat terhadap penggunaan lembaga pembiayaan. ${ }^{9}$

\footnotetext{
${ }^{5}$ Rayyan Sugangga dan Erwin Hari Sentoso, 'Perlindungan Hukum Terhadap Pengguna Pinjaman Online (PINJOL) Ilegal' (2020) 1 Pakuan Justice Jurnal of Law.[47-61].

${ }^{6}$ Suci Kamilah, 'Tinjauan Yuridis Normatif Tindak Pidana Yang Dilakukan Oleh Kreditur Fintech Kepada Debitur Yang Telat Dalam melakukan Pelunasan' (2020) Skripsi Fakultas Hukum Universitas Muhammadiyah Malang.

${ }^{7}$ H2 Ventures dan KPMG, 2018 Fintech100- Leading Global Fintech Innovators (H2 Ventures dan KPMG 2018).[4].

${ }^{8}$ Otoritas Jasa Keuangan, 'Yuk Mengenal Fintech! Keuangan Digital Yan Tengah Naik Daun', <https:/ / sikapiuangmu.ojk.go.id/FrontEnd/CMS/Article/10468> . Dikunjungi pada 12 Desember 2021.

${ }^{9}$ Katadata Insight Center, 'Perilaku Konsumen E-Commerce Indonesia Juni 2021' (2021), < https:/ / katadata.co.id/perilaku-ecommerce>, dikunjungi pada 15 Juni 2021.
} 
Salah satu keunggulan kegiatan/aktifitas penawaran jasa pinjaman melalui aplikasi online, yaitu aplikasi yang memungkinkan bagi konsumen tidak perlu bertatap muka dan datang langsung ke lembaga pembiayaan atau lembaga perbankan untuk mendapatkan sejumlah pinjaman uang. Layanan Jasa Pinjaman secara online jelas diatur dalam Peraturan Otoritas Jasa Keuangan Nomor (selanjutnya disebut POJK) 77 Tahun 2016 tentang Layanan Pinjam Meminjam Uang Berbasis Teknologi Informasi yang menjelaskan mengenai penyelenggaraan layanan jasa keuangan berbasis teknologi informasi, yang juga diejawantahkan dalam Pasal 3 ayat (1) huruf d Peraturan Bank Indonesia Nomor 19/12/PBI/2017 Tahun 2017 tentang Penyelenggaraan Teknologi Finansial yang menyebutkan bahwa salah satu kategori penyelenggaraan teknologi finansial adalah pinjaman, pembiayaan, dan penyediaan modal. ${ }^{10}$

Kemudahan lain yang didapatkan oleh konsumen apabila meminjam uang secara melalui peer to peer landing adalah cukup dengan melakukan pemasangan aplikasi pinjaman online di ponsel pintar, kemudian menggunggah identitas yang tertera pada Kartu Tanda Penduduk (KTP) dan nomor rekening milik konsumen maka tidak lama dana pinjaman akan segera masuk ke dalam rekenin konsumen. Namun disamping cepatnya proses pencairan dana pinjaman, ada hal-hal yang perlu dipertimbangkan sebagai implikasi dari proses pencairan dana yang cenderung instan, diantaranya tidak adanya transparansi bunga pinjaman yang sangat tinggi, data peminjam yang sangat mudah disebarluaskan dan pada beberapa kasus terjadi penyalahgunaan data serta penagihan yang tidak sesuai dengan aturan.

Padahal, mengacu pada Pasal 29 Peraturan Otoritas Jasa Keuangan Nomor 77 Tahun 2016 tentang Layanan Pinjam Meminjam Uang Berbasis Teknologi Informasi yang menjelaskan mengenai perlindungan pemberi dan penerima pinjaman, mengenai penyelenggaraan Fintech wajib menerapkan prinsip: Transparansi;

${ }^{10}$ Sovia Hasanah, ‘Langkah Yang Bisa Dilakukan Jika Terlilit Utang Kredit Online’ (Hukum Online , 2018) <https://www.hukumonline.com/klinik/detail/1t5b974c6b25852/langkah-yang-bisa-dilakukan-jika-terlilit-utang-kredit-ionline-i>, dikunjungi pada 15 Juni 2021. 
Perlakuan yang adil; keandalan; kerahasiaan; keamanan data; dan penyelesaian sengketa pengguna secara sederhana cepat dan biaya terjangkau. ${ }^{11}$ Berdasarkan regulasi tersebut, maka perlu adanya perlindungan bagi konsumen pinjaman online dalam bentuk undang-undang yang berbasis finansial teknologi yang dapat mengakomodir perlindungan hukum bagi penggunana jasa layanan pinjaman online (peer to peer lending). Dalam pembangunan hukum tersebut setidaknya harus memperhatikan kultur, subtansi dan struktur agar pembentukanya dapat efisien dan efektif. ${ }^{12}$

\section{Metode Penelitian}

Pada penelitian ini akan digunakan metode penelitian yuridis normatif atau penelitian hukum doctrinal, ${ }^{13}$ dengan pendekatan peraturan perundang -undangan yaitu penelitian yang mengutamakan bahan hukum yang berupa peraturan perundang-undangan sebagai bahan acuan dasar dalam melakukan penelitian. Marzuki menjelaskan pendekatan perundang-undangan (statute approach) biasanya digunakan untuk meneliti peraturan perundang-undangan yang dalam bentuk penormaannya masih terdapat kekurangan atau malah menyuburkan praktek penyimpangan baik dalam tataran teknis atau dalam pelaksanaannya dilapangan. ${ }^{14}$ Dimana penulis akan melakukan analisis secara mendalam terhadap peraturan perundang-undangan terkait yang mengatur mengenai fintech untuk menemukan adanya kesesuian atau tidak dalam antara hukum dan praktek aktifitas layanan jasa fintech dalam masyarakat. Kemudian akan dilakukan juga analisis secara konseptual (conceptual approach) dengan menggunakan konsep-konsep hukum terkait sehingga nantinya penelitian ini diharapkan dapat dijadikan kajian awal dalam memberikan perlindungan bagi konsumen pinjaman online di Fintech dalam urgensi pembentukan undang - undang pinjaman online (fintech).

\footnotetext{
${ }^{11}$ ibid.

12 Soetandyo Wignjosoebroto, Hukum Yang Tak Kunjung Tegak (Komisi Yudisial Republik

${ }^{13}$ Sukisno B, Karakter Penelitian Hukum Normatif dan Sosiologis (Puskumbangsi Leppa UGM).[8].

14 ibid.[133].
} Indonesia 2015).[4]. 


\section{Legalitas Penyelenggaraan Layanan Pinjam Meminjam Online (Peer To Peer Lending) Di Indonesia}

Financial technologi merupakan salah satu bentuk kemajuan baru dalam bidang keuangan seiring dengan perkembangan teknologi informasi, Pada saat ini hampir seluruh lini dan aspek kehidupan ditransformasikan dan tidak dapat terlepas dari system digital. Salah satu bidang yang diminati dalam aspek ekonomi adalah dalam hal transaksi yang berkaitan erat dengan keuangan. Hal ini dimulai mulai dari aspek transaksi perdagangan atau bisnis online dan pemasaran hingga munculnya lembaga pembiayaan online atau yang dikenal dengan pinjaman online (peer to peer landing). Hampir seluruh aktifitas tersebut dilakukan pada saat ini dengan sarana bentuk digital. Penggunaan digital sistem ini, di satu sisi sistem keuangan digital (digital finance system) ini menawarkan kemudahan dan efisiensi dalam mengoptimalkan potensi ekonomi, namun apabila dilihat dari disisi lain tidak dapat dibantah, masih banyak menimbulkan permasalahan hukum yang harus dibenahi, khususnya dalam transaksi pinjaman online.

Perlindungan hukum bagi konsumen di Indonesia secara umum diatur dalam Undang-Undang Nomor 8 Tahun 1999 tentang Perlindungan Konsumen (Selanjutnya disebut “UUPK”). Dalam pasal 4 UUPK dijelaskan bahwa keamanan, kenyamanan dan keselamatan konsumen adalah hal utama dalam perlindungan konsumen dan UUPK sendiri memiliki 3 (tiga) prinsip dasar yaitu: ${ }^{15}$

1. Hak untuk mendapatkan/membeli barang dan/atau jasa dengan harga yang sesuai dengan harga pasar (wajar);

2. Hak untuk menghindarkan konsumen dari kerugian;

3. Hak untuk mendapatkan penyelesaian terhadap permasalahan terkait sengketa perlindungan konsumen.

Dalam Undang-Undang Nomor 8 Tahun 1999 tentang Perlindungan Konsumen dijelaskan bahwa Konsumen adalah setiap orang pemakai barang/ dan jasa yang tersedia dalam masyarakat, baik bagi kepentingan sendiri, keluarga,

${ }^{15}$ Abdul Halim Barkatullah, hak-hak konsumen (Nusa Medina 2010).[25]. 
orang lain maupun mahkluk hidup lain dan tidak melakukan perdagangan. Dalam Undang-Undang Nomor 8 Tahun 1999 kemudian dikenal berbagi prinsip prinsip yang timbul karena adanya hubungan hukum yang erat antara konsumen dengan pelaku usaha, yang akan diuraikan sebagai berikut: ${ }^{16}$

a. Caveat Emptor (Let The Buyer Beware)

Jika diterjemahkan ke dalam bahasa Indonesia Caveat Emptor memiliki arti pembeli harus berhati - hati dalam suatu pembelian atau dalam terjemahan bahasa Inggrisnya let the buyer beware. Makna dari Caveat Emptor sendiri adalah pembeli atau konsumen yang melakukan kelalaian dalam suatu pembelian harus menanggung akibatnya sendiri. Menurut prinsip ini hubungan antara pelaku usaha dan konsumen dianggap setara sehingga sehingga konsumen tidak memerlukan perlindungan khusus.

Dalam suatu proses jual-beli antara pelaku usaha dan konsumen, biasanya konsumen tidak memiliki informasi yang baik terhadap suatu barang yang dibelinya. Hal ini dapat terjadi karena pelaku usaha yang tidak memberikan informasi secara terbuka terhadap produk yang ia keluarkan atau karena konsumen itu sendiri tidak memiliki pengetahuan yang cukup. Sehingga oleh karena hal ini maka apabila konsumen mengalami kerugian karena suatu produk maka ia tidak dapat secara langsung meminta atau menuntut pertanggungjawaban produsen atas kerugiannya, karena konsumen kerugian yang diterima konsumen karena ia lalai dan tidak berhati-hati saat melakukan pembelian.

b. The Due Care Theory

Prinsip ini juga memiliki sebutan lain yaitu duty of care. Dalam prinsip ini seorang pelaku usaha wajib untuk berhati - hati saat memasarkan produknya baik barang ataupun jasa kepada pembeli atau konsumen. Apabila pelaku usaha sudah menjalankan prinsip kehati - hatian ini maka pelaku usaha tidak dapat dipersalahkan apabila konsumen mengalami kerugian dikemudian hari. Apabila dilihat secara a contrario untuk dapat meminta pertanggungjawaban dari pelaku

${ }^{16}$ Risna Kartika, 'Analisis Peer to Peer Lending di Indonesia' (2020) 12 AKUNTABILITAS: Jurnal Ilmiah ilmu-ilmu ekonomi.[75-86]. 
usaha maka konsumen harus dapat membuktikan bahwa memang pelaku usaha tersebut melanggar prinsip kehati-hatian.

Dalam prinsip ini apabila konsumen tidak dapat membuktikan bahwa pelaku usaha melanggar prinsip kehati-hatian maka ia tidak dapat melakukan gugatan ganti rugi kepada pelaku usaha. Ditinjau dari hukum pembuktian yang berlaku di Indonesia khususnya yang di atur didalam Pasal 1865 BW yang menjelaskan bahwa apabila seseorang menyatakan bahwa ia memiliki hak atau membantah orang maka ia harus dapat membuktikannya. Sehingga dari pasal tersebut beban pembuktian juga dibagi kepada penggugat.

c. The Privity of Contract

Dalam Pasal 1340 BW menjelaskan bahwa suatu perjanjian hanya memiliki keterikatan diantara pihak-pihak yang melakukan perjanjian tersebut. Dari pasal tersebut munculah kemudian asas Privity of Contract. Dari pengertian dalam Pasal 1340 BW tersebut maka dapat dipahami bahwa konsumen adalah pihak yang harus dilindungi. Hal ini karena munculnya hubungan kontraktual antara konsumen dengan pelaku usaha. Sehingga berdasarkan asas ini apabila pelaku usaha merugikan konsumen maka pelaku usaha tersebut dapat digugat dengan dasar gugatan wanprestasi.

Sehingga dalam menjalankan layanan pinjam meminjam uang online harus sejalan dengan prinsip - prinsip yang ada dalam UUPK tersebut. Namun secara khusus pengaturan mengenai layanan pinjam meminjam online telah diatur dalam Peraturan Otoritas Jasa Keuangan No. 77/POJK.01/2016 tentang layanan jasa pinjam meminjam uang berbasis teknologi informasi (selanjutnya disebut POJK 77/2016).

Dalam Pasal 1 angka 3 POJK 77/2016 dijelaskan bahwa layanan pinjam meminjam uang berbasis teknologi adalah penyelenggaraan layanan jasa keuangan dengen mempertemukan pemberi pinjaman dan penerima pinjaman untuk melakukan pinjam meminjam melalui system elektornik dengan jaringan internet. Kemudian dalam Pasal 2 POJK 77/2016, yang dapat menjadi lembaga jasa keuangan adalah badan hukum dengan bentuk perseroan terbatas dan koperasi. 
Lembaga jasa keuangan yang melakukan pinjam meminjam online sebagaimana yang diatur di POJK 77/2016 wajib untuk mendaftarkan dan mengurus perizinan usahanya sebagaimana diatur dalam Pasal 7 POJK 77/ 2016.

Dalam layanan peer to peer landing hubungan hukum yang terbentuk antara penyelenggara layanan peer to peer lending, penerima pinjaman dan pemberi pinjaman sesuai dengan Pasal 18 POJK 77/2016 adalah sebagai berikut :

a. Hubungan hukum antara penyelenggara peer to peer lending dengan pemberi pinjaman ; dan

b. Hubungan hukum antara pemberi pinjaman dengan penerima pinjaman.

Dari 2 (dua) hubungan hukum yang terbentuk tersebut dapat dilihat bahwa tidak ada hubungan hukum yang terbentuk antara penyelenggara peer to peer lendingdengan penerima pinjaman, hal ini karena memang tujuan dari adanya layanan peer to peer lending adalah sebagai perantara antara penerima pinjaman dengan pemberi pinjaman untuk dapat melakukan pinjam-meminjam secara online.

Dari 2 (dua) hubungan hukum yang terbentuk akibat penyelenggaraan layanan peer to peer lending tersebut dapat dilihat bahwa bentuk pinjam meminjam uang secara online dalam platform peer to peer lendingberbeda dengan pinjam meminjam yang diatur dalam pasal 1754 BW. Dalam pasal 1754 BW diatur bahwa dalam pinjam -meminjam, pemberi pinjaman memberikan secara langsung suatu benda dalam jumlah tertentu kemudian mengembalikannya dalam jumlah sama. ${ }^{17}$ Apabila dibandingkan dengan system pinjam meminjam uang secara online terdapat perbedaan yaitu apabila pinjam meminjam uang secara online terdapat penyelengara peer to peer lending yang menjadi penghubung antara pemberi pinjaman dan penerima pinjaman. Hal ini membuat adanya celah apabila terjadi masalah antara penyelenggara peer to peer lending dengan penerima pinjaman karena akan sulit bagi penerima pinjaman untuk melakukan penuntutan atas kerugian kepada penyelenggara peer to peer lending tanpa didasari hubungan hukum yang kuat.

\footnotetext{
${ }^{17}$ Ratna Hartanto dan Juliyani Purnama Ramli , 'Hubungan Hukum Para Pihak dalam Peer to Peer Lending'(2018) 25 Jurnal Hukum Ius Quia Iustum.[322].
} 
Selain itu dalam layanan pinjam meminjam uang secara online peer to peer lending tidak dibuat perjanjian secara tertulis karena jaminan yang diberikan oleh penerima pinjaman hanya berupa kartu tanda penduduk (KTP) tanpa ada agunan atau jaminan lain, sehingga aspek hukum tertulis seperti adanya tanda tangan kedua belah pihak dalam perjanjian sebagai bentuk kesepakatan tidak terlaksana dan dapat menjadi celah. karena kemudian penyelenggara peer to peer lending dapat melakukan wanprestasi dengan memberikan suku bunga tambahan yang tinggi atau mengubah jatuh tempo secara sepihak yang tentunya sangat merugikan konsumen/penerima pinjaman.

Sehingga, penting bagi masyarakat untuk mengatahui bahwa perlindungan hukum tersedia dan sangat diperlukan oleh para konsumen. Adapun ketentuan yang mengatur mengenai pinjaman online dijamin ole Otoritas Jasa Keuangan dengan mengeluarkan beberapa peraturan berikut:

1) POJK Nomor 1/POJK.07/2013 Tentang “Perlindungan Konsumen Sektor Jasa Keuangan". Prinsip dasar yang digunakan dalam peraturan ini diantaranya sebagai berikut:

a. Adanya transparansi;

b. memberikan perlakuan yang adil terhadap konsumen;

c. memiliki pengalaman dan keandalan;

d. menjaga keamanan dan kerahasiaan data konsumen;

e. menerima pengaduan dari konsumen dan kemudian menyediakan penyelesaian sengketa bagi konsumen secara sederhana, pasti, cepat dan dengan tidak memakan banyak biaya.

2) POJK No. 77/ POJK.01/2016 tentang-Layanan-Pinjam Meminjam Uang Berbasis Teknologi-Informasi.

3) Surat Edaran Otoritas Jasa Keuangan Nomor : 18/ SEOJK.02/2017 Setelah berlakunya POJK nomor 77/POJK.01/2016 tentang “Layanan Pinjam meminjam Uang Berbasis Teknologi Informasi", Otoritas Jasa Keuangan telah mengeluarkan ketentuan tentang pelaksanaan tata kelola dan manajemen risiko Teknologi Informasi pada sistem pinjam meminjam uang berbasis teknologi dalam SEOJK Nomor: 18/ SEOJK.02/2017 yang telah resmi dijadikan pedoman sejak tanggal 18 April 2017. 
4) Surat Edaran Otoritas Jasa Keuangaan No.014/SEOJK.07/2014 tentang Kerahasiaan dan Keamanan Data dan/atau Informasi Pribadi Konsumen.

\section{Analisis Perlindungan Konsumen dalam Layanan Peer to Peer Landing}

Kemajuan penggunan sistem digital pada bidang keuangan telah turut serta menyebabkan peningkatan kapitalisasi pembiayaan atau pendanaan bagi para pelaku usaha yang belum terjangkau oleh sektor perbankan. Hal ini diwujudkan melalui layanan pinjaman online (peer to peer lending) yang terus mendorong pertumbuhan ekonomi khususnya sektor keuangan. Melihat kehadiran pinjaman online dalam financial technology, membantu lembaga keuangan dalam memberikan pinjaman kepada masyarakat yang belum mendapat akses. Dapat dikatakan dengan adanya fintech, teknologi yang ditawarkan bisa memberikan akses dan menghantarkan solusi finasial. ${ }^{18}$

Menurut data yang dihimpun oleh Otoritas Jasa Keuangan per 6 Oktober 2021 terdapat 106 perusahaan yang terdaftar sebagai perusahaan fintech lending berizin dan terdaftar. ${ }^{19}$ Sementara di sisi lain Satgas Waspada Investasi (SWI) OJK per 12 November 2021 telah melakukan pemblokiran terhadap 3.631 situs perusahaan penyelenggara peer to peer lending digital berdasarkan kurang lebih 8.000 laporan masyarakat dan konsumen yang menjadi korban.

Transaksi pinjaman online (peer to peer) masih banyak meninggalkan polemik bagi para penggunanya khususnya pihak penerima pinjaman, beberapa masalah dalam peyelenggaraan peer to peer lending diantaranya:

\section{a. Besaran Bunga Yang Tidak Sesuai Dengan Kesepakatan Awal Dan/ Atau Dinaikkan Secara Sepihak.}

Mengenai pemberian suku bunga menurut Yahya Harahap perjanjian pinjam meminjam diperbolehkan untuk memperjanjikan bunga atas pinjaman uang

${ }^{18}$ Douglas W Arner, et all, 'The Evolution Of Fintech: A New Post Crisis Paradigm' (2015) 50 University of Hongkong Faculty Of Law Research Paper.[3].

19 Otoritas Jasa Keuangan, 'Perusahaa Fintech Lending Berizin dan Terdaftar di OJK', <https://www.ojk.go.id/id/kanal/iknb/financial-technology/Documents/PENYELENGGARA\%20FINTECH\%20TERDAFTAR\%20DAN\%20BERIZIN\%20DI\%20OJK\%20PER\%206\%20OKTOBER\%202021.pdf> dikunjungi pada 12 desember 2021. 
atau barang namun kemudian diatur dala Pasal 1765 bahwa bunga yang diperjanjikan tersebut harus dinyatkan secara tertulis. ${ }^{20}$ Namun kenyataannya dalam perjanjian pinjam meminjam yang dilakukan dengan sarana peer to peer landing masih banyak pemberi pinjaman online yang tidak memperjanjikan atau memperhitungkan bunga dari awal sehingga konsumen tidak mengerti berapa jumlah pasti bunga yang sebenarnya dibayarkan atas pinjaman tersebut dan hanya pihak kreditur yang mengetahui berapa bunga yang dibebankan.

\section{b. Proses Penagihan Yang Didalamnya Terdapat Tindak Pidana Kekerasan}

Dalam proses penagihan pembayaran atas pinjaman online juga sering disertai tindak kekerasan yang dilakukan oleh juru tagih atau debt collector dari pihak perusahaan penyedia jasa layanan tersebut. Dalam ketentuan Surat Edaran Bank Indonesia Nomor 11/10/DASP Perihal Penyelenggaraan Kegiatan Alat Pembayaran seorang Debt Collector sebagai penerima kuasa dari perusahaan diperbolehkan melakukan penagihan selama dalam proses tersebut dilakukan dengan cara yang tidak melawan hukum. Namun pelaksanaan di lapangan banyak terjadi kasus penagihan yang disertai tindak kekerasan baik melalui secara langsung maupun melalui media elektronik. Tindak kekerasan secara langsung berupa kekerasan fisik agar nasabah melunasi hutangnya dapat dijerat ketentuan Pasal 335 ayat (1) KUHP. Tindak kekerasan verbal atau terror ancaman melalui media eletronik juga sering diterima oleh masyarakat dengan tujuan agar nasabah tertekan dan segera melunasi hutangnya termasuk sebagai suatu kejahatan cyber crime yang dapat dijerat oleh Undang - Undang Nomor 19 Tahun 2016 tentang Perubahan atas Undang - Undang Nomor 11 Tahun 2008 tentang Informasi dan Transaksi Elektronik (UU ITE).

\section{c. Tidak Ada Jaminan Keamanan Dalam Penyalahgunaan Data Pribadi.}

Bahwa untuk menjaga keutuhan, kerahasiaan dan ketersediaan suatu data pribadi, data transaksi serta data keuangan seorang penyelenggara atau penyedia peer to peer landing wajib menjaga dan mengelola data tersebut

${ }^{20}$ Op.Cit, Hardika Fajar. 
dari awal diperoleh hingga kemudian dimusnahkan. Meskipun sudah diatur dalam suatu peraturan naun ternyata dalam pelaksanaan nyatanya, peraturan tersebut belum dapat secara maksimal memberikan perlindungan bagi data pribadi yang juga merupakan privasi dari setiap individu. Peraturan mengenai larangan untuk menyalahhgunakan data pribadi ada dalam UU ITE. Kemudian secara lengkapnya diatur dalam Peraturan Menteri Kominfo No. 20 Tahun 2016 tentang Perlindungan Data Pribadi dalam Sistem Elektronik (PM 20/2016) dimana peraturan ini sudah berlaku sejak bulan desember 2016. Dalam peraturan ini dijelaskan bahwa yang dimaksud dengan perlindungan data pribadi adalah perlindungan yang mencakup pengumpulan, pengolahan, perolehan, penganalisaan, penyimpanan, penampilan, pengiriman, pengumuman, penyebarluasan dan pemusnahan data pribadi.

Dari berbagai polemik yang telah dikemukan diatas mengindikasikan bahwa peraturan yang mengatur mengenai penyelenggaraan peer to peer lending belum secara maksmimal dapat menekan munculnya perusahaan penyelenggara peer to peer tanpa izin. Aturan yang belum mampu mengakomodasi perkembangan dalam penyelenggaraan peer to peer lending hingga saat ini memberikan suatu permasalahan hukum baru yang berkemungkinan terus bermunculan dan merugikan masyarakat. OJK sebagai lembaga yang memiliki kewenangan dalam menerima pengaduan masyarakat juga tidak dapat berbuat banyak dalam menyelesaikan laporan yang masuk dikarenakan terhalang oleh aturan hukum yang belum jelas. OJK bahkan mengaku dalam penerimaan laporan yang berasal dari masyarakat terkait permasalahan penyelenggaraan peer to peer lending ini, khususnya dalam hal pinjol illegal tidak dapat memberikan penyelesaian secara nyata. ${ }^{21} \mathrm{Hal}$ ini dikarenakan untuk penyelenggara pinjaman online secara illegal perusahaan penyedia layanan tersebut tidak terdaftar di OJK dan data terkait perusahaan tidak dapat ditemukan yang berujung tidak dapat diprosesnya aduan

${ }^{21}$ CNN Indonesia, 'Dapat Aduan Pinjol Ilegal, OJK Akui Tak Tahu Harus Hubungi Kemana', <https://www.cnnindonesia.com/ekonomi/20211204141341-78-729817/ dapat-aduan-pinjol-ilegal-ojk-akui-tak-tahu-harus-hubungi-kemana> dikunjungi pada 12 desember 2021. 
dari masyarakat tersebut. Hingga saat ini dapat dikatakan OJK hanya dapat menangani laporan atas perusahaan pinjaman online yang terdaftar saja.

Pelaksanaan pemrosesan pengaduan dari masyarakat ini belum dapat dilakukan secara maksimal karena belum adanya suatu bentuk pengawasan konkrit yang dapat diberikan oleh negara. Masyarakat sebagai konsumen dalam pelayanan penyedia pinjaman online perlu diberikan suatu perlindungan hukum yang tegas agar dapat memberikan kepastian hukum yang jelas melalui suatu landasan hukum yang kuat. Maka dari itu, melalui Peraturan perundang-undangan yang telah disebutkan dan dijelaskan diatas serta analisis yang dilakukan penulis melalui fakta-fakta yang relevan, peraturan perundang-undangan yang ada saat ini terbukti belum optimal dalam mengakomodir hak perlindungan konsumen perihal pinjaman online yang dalam hal ini disebut fintech.

Untuk saat ini Peraturan perundang-undangan yang berhubungan dengan fintech dan telah dianalisis oleh penulis diatas merupakan pengaturan yang berasal dari ketentuan Peraturan Otoritas Jasa Keuangan Nomor 77 Tahun 2016 tentang Layanan Pinjam Meminjam Uang Berbasis Teknologi Informasi yang secara hierarkis berada dibawah Undang-undang.

Peraturan Otoritas Jasa Keuangan merupakan salah satu bentuk jenis peraturan pelaksanaan yang seharusnya mengatur mengenai teknis pelaksanaan sesuai amanat undang-undang. Dalam hal ini Peraturan Otoritas Jasa Keuangan merupakan peraturan atas otoritas lembaga maupun kepala lembaga yang berwewenang.

Sebagai peraturan pelaksana, jika kita analisis berdasarkan sifat hierarkis suatu peraturan perundang-undangan menurut Undang- Undang nomor 12 Tahun 2011 Tentang Jenis dan Hierarki Peraturan perundang-undangan, peraturan pelaksana yang dalam hal ini Peraturan Otoritas Jasa Keuangan Nomor 77 Tahun 2016 tentang Layanan Pinjam Meminjam Uang Berbasis Teknologi Informasi dibuat atas dasar kewenangan delegasi pemerintah pusat kepada Badan Otoritas Jasa Keuangan (OJK), yang dalam hal ini merupakan pihak eksekutif (pelaksana).

Pemberian delegasi pembuatan peraturan pelaksanaan kepada eksekutif mengandung risiko kurangnya publikasi dan diseminasi. Kurangnya pengawasan 
serta kurangnya publikasi dan diseminasi mengakibatkan ketentuan yang dibuat dalam peraturan pelaksanaan berpotensi menyimpangi, memperluas, atau mempersempit materi undang-undang. ${ }^{22}$ Selain itu, lembaga eksekutif juga cenderung membuat ketentuan yang menguntungkan dirinya ketika terdapat ketentuan dalam undang-undang yang tidak jelas atau bahkan tidak diatur, layaknya mengenai fintech yang tidak diatur secara eksplisit dalam undangundang. Hal ini terbukti melalui pembahasan yang telah dibahas oleh penulis, bahwa minimnya pengetahuan masyarakat mengenai perlindungan konsumen dalam fintech yang mengakibatkan masyarakat cenderung kegabah dalam memanfaatkan dan mengakses fintech illegal yang kemudian berdampak pada gagalnya masyarakat untuk melindungi dirinya dari kerugian sebagai dampak penggunaan pinjaman online illegal.

Maka dari itu, undang-undang merupakan instrumen yang sangat tepat untuk memberikan kepastian hukum kepada konsumen pengguna pinjaman online. dalam prinsipnya, secara hierarkis undang-undang memiliki kedudukan yang lebih tinggi daripada peraturan Lembaga resmi negara seperti OJK. undangundang juga dibuat dengan melibatkan pihak legislatif dan eksekutif sebagai pelaksana, artinya bukan hanya mengenai peraturannya saja yang akan diatur melalui undang-undang, tapi juga akan ada pendelegasian dari legislatif kepada eksekutif mengenai teknis pelaksanaan dari undang-undang tersebut. Hal ini memberikan jaminan terhadap pelaksanaan suatu undang-undang, karena ada dasar peraturan yaitu undang-undang yang mendasari lahirnya peraturan lembaga resmi negara sebagai tata pelaksana dari suatu peraturan.

Melalui undang-undang kita dapat menghindari potensi penyalahgunaan kekuasaan (abuse of power) yang dapat dilakukan oleh pihak eksekutif, dalam hal ini OJK, karena ada dasar hukum mengikat yang membatasi kekuasaan OJK sebagai lembaga resmi negara yang berkewenangan atas delegasi pemerintah pusat.

${ }^{22}$ Humas, 'Mengapa Undang-Undang Perlu Peraturan Pelaksanaan?' (Sekretaris Kabinet RI, 2015) < https:/ / setkab.go.id/mengapa-undang-undang-perlu-peraturan-pelaksanaan/>, dikunjungi pada 22 Juni 2021. 


\section{Kesimpulan}

Peraturan Otoritas Jasa Keuangan Nomor 77 Tahun 2016 tentang Layanan Pinjam Meminjam Uang Berbasis Teknologi Informasi yang saat ini mengatur mengenai financial technology (fintech), terbukti kurang optimal dalam memberikan perlindungan konsumen dalam pinjaman online. Sehingga, perlu adanya Undang-undang yang memiliki kedudukan lebih tinggi dan kekuatan hukum mengikat untuk mengatur secara komperhensif dan eksplisit mengenai segala ketentuan yang berkaitan dengan financial technology (fintech). Maka dari itu, beberapa hal yang dapat penulis simpulkan: Pertama, dalam prinsipnya, secara hierarkis undang-undang memiliki kedudukan yang lebih tinggi daripada peraturan Lembaga resmi negara seperti OJK. Kedua, undang-undang dibuat dengan melibatkan pihak legislatif dan eksekutif sebagai pelaksana, yang dalam hal ini undang-undang dibuat dengan mempertimbangkan serta mengamanatkan peraturan materiil dan formil dari hadirnya undang-undang yang dibuat. Hal ini memberikan jaminan terhadap pelaksanaan suatu undang-undang, karena ada dasar peraturan yaitu undang-undang yang mendasari lahirnya peraturan lembaga resmi negara sebagai tata pelaksana dari suatu peraturan. Pembentukan suatu lembaga independen baru atau suatu divisi khusus untuk membidangi urusan terkait pinjaman online dirasa perlu untuk memberikan suatu pengawasan khusus bagi setiap permasalahan yang muncul. Ketiga, menghindari potensi penyalahgunaan kekuasaan (abuse of power) yang dapat dilakukan oleh pihak eksekutif, dalam hal ini OJK, karena ada dasar hukum mengikat yang membatasi kekuasaan OJK sebagai lembaga resmi negara yang berkewenangan atas delegasi pemerintah pusat. Sehingga jika ada undang-undang yang mengatur secara eksplisit dan komperhensif mengenai fintech, maka ada ada batas kewenangan yang jelas dari OJK mengenai pengelolaan dan pengadaan fintech. 


\section{Daftar Bacaan}

\section{Buku}

Abdul Halim Barkatullah, hak-hak konsumen (Nusa Medina 2010).

Peter Mahmud Marzuki, Penelitian Hukum: Edisi Revisi (Kencana Prenada Media Group 2008).

Soetandyo Wignjosoebroto, Hukum Yang Tak Kunjung Tegak (Komisi Yudisial Republik Indonesia 2015).

Sukisno B, Karakter Penelitian Hukum Normatif dan Sosiologis (Puskumbangsi Leppa UGM).

Suyikno, Hukum Ekonomi (UIN Sunan Ampel bekerjasama dengan Government of Indonesia (GoI) dan Islamic Development Bank (IDB) 2015).

Jurnal

Aam Slamet Rusydiana, 'Bagaimana Mengembangkan Industri Fintech Syariah di Indonesia? Pendekatan Interprettive Structural Model (ISM)' (2018) 6 Jurnal Al-Muzara'ah.

Andi Arvian Agung dan Erlina, 'Perlindungan Hukum Terhadap Konsumen Pengguna Jasa Pinjaman Online'(2020) 2.

Douglas W Arner, et all, 'The Evolution Of Fintech : A New Post Crisis Paradigm' (2015) 50 University of Hongkong Faculty Of Law Research Paper.

Erna Prilliasari, 'Pentingnya Perlindungan Data Pribadi Dalam Transaksi Pinjaman' (2013) 49.

Hardika Fajar Ardianto, et all, 'Perlindungan Hukum Terhadap Konsumen Dalam Transaksi Online (2015) 8.

Istiqamah , 'Analisis Pinjaman Online Oleh Fintech Dalam Kajian Hukum Perdata' (2019) 6.

Posma Sariguna Johnson Kennedy, 'Literature Review: Tantangan Terhadap Ancaman Distruptif dari Financial Technology dan Peran Pemerintah Dalam Menyikapinya' (2017) 6 Prosiding Forum Keuangan dan Bisnis Indonesia (FKBI).

Ratna Hartanto dan Juliyani Purnama Ramli , 'Hubungan Hukum Para Pihak dalam Peer to Peer Lending'(2018) 25 Jurnal Hukum Ius Quia Iustum. 
Helena Toshely, dkk: Analisis Faktor Perlindungan...

Rayyan Sugangga dan Erwin Hari Sentoso, 'Perlindungan Hukum Terhadap Pengguna Pinjaman Online (PINJOL) Ilegal' (2020) 1.

Risna Kartika, 'Analisis Peer to Peer Lending di Indonesia' (2020) 12 AKUNTABILITAS: Jurnal Ilmiah ilmu-ilmu ekonomi

\section{Skripsi}

Suci Kamilah, 'Tinjauan Yuridis Normatif Tindak Pidana Yang Dilakukan Oleh Kreditur Fintech Kepada Debitur Yang Telat Dalam melakukan Pelunasan' (2020) Skripsi Fakultas Hukum Universitas Muhammadiyah Malang.

\section{Laman}

CNN Indonesia, ‘Dapat Aduan Pinjol Ilegal, OJK Akui Tak Tahu Harus Hubungi Kemana',<https://www.cnnindonesia.com/ekono mi/20211204141341-78-729817/ dapat-aduan-pinjol-ilegal-ojk-akui-taktahu-harus-hubungi-kemana>, dikunjungi pada 12 Desember 2021.

Humas, 'Mengapa Undang-Undang Perlu Peraturan Pelaksanaan?' (Sekretaris Kabinet RI, 2015) < https:/ / setkab.go.id/mengapa-undang-undang-perluperaturan-pelaksanaan/>, dikunjungi pada 22 Juni 2021.

Katadata Insight Center, 'Perilaku Konsumen E-Commerce Indonesia Juni 2021' (2021), < https://katadata.co.id/ perilaku-ecommerce>, dikunjungi pada 15 Juni 2021.

Otoritas Jasa Keuangan, 'YukMengenal Fintech! Keuangan Digital Yan Tengah Naik Daun', https:// sikapiuangmu.ojk.go.id/FrontEnd/CMS/Article/10468, dikunjungi pada 12 Desember 2021.

Sovia Hasanah, 'Langkah Yang Bisa Dilakukan Jika Terlilit Utang Kredit Online' (Hukum Online , 2018) <https://www.hukumonline.com/klinik/detail/ lt5b974c6b25852/langkah-yang-bisa-dilakukan-jika-terlilit-utang-kreditionline-i>, dikunjungi pada 15 Juni 2021.

\section{Perundang-undangan}

Undang - Undang Nomor 8 Tahun 1999 Tentang Perlindungan Konsumen (Lembaran Negara Republik Indonesia Tahun 1999 Nomor 42, Tambahan Lembaran Negara Nomor Republik Indonesia Nomor 3821).

Undang- Undang nomor 12 Tahun 2011 Tentang Jenis dan Hierarki Peraturan perundang-undangan (Lembaran Negara Republik Indonesia Tahun 2011 Nomor 82, Tambahan Lembaran Negara Nomor 5234). 
Undang - Undang Nomor 19 Tahun 2016 Tentang Informasi dan Transaksi Elektronik (Lembaran Negara Republik Indonesia Tahun 2016 Nomor 251, Tambahan Lembaran Negara Republik Indonesia Nomor 5952).

Peraturan Otoritas Jasa Keuangan Nomor 77 Tahun 2016 tentang Layanan Pinjam Meminjam Uang Berbasis Teknologi Informasi.

Peraturan Bank Indonesia Nomor 19/12/PBI/2017 Tahun 2017 tentang Penyelenggaraan Teknologi Finansial.

How to cite: Helena Toshely Sasmita, Suci Kamilah, Rina Irsni Wardodo dan Thody Daniel Satya Wira Wicaksana, 'Analisis Faktor Perlindungan Konsumen Dalam Urgensi Pembentukan Undang-Undang Pinjaman Online (Peer To Peer Lending)' (2022) Vol. 5 No. 1 Media Iuris. 
--Halaman ini sengaja dibiarkan kosong-- 